\title{
How much eculizumab should be replaced after antibody removal for treatment of antibody-mediated rejection?
}

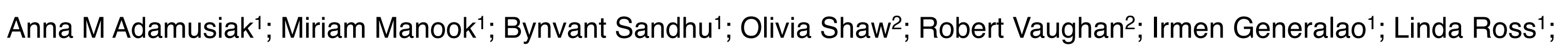
Professor Anthony Dorling ${ }^{1}$; Nicos Kessaris ${ }^{1}$; Professor Nizam Mamode ${ }^{1}$

1 - Department of Renal Transplantation at Guy's Hospital in London

2 - Clinical Transplantation Laboratory at at Guy's Hospital in London

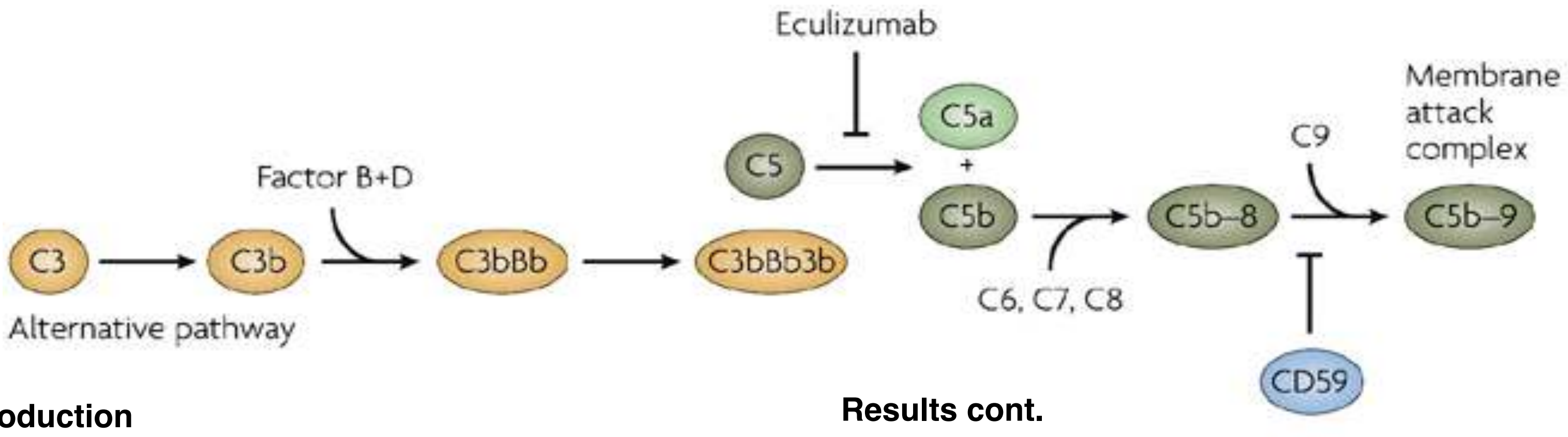

\section{Introduction}

Antibodies directed against either ABO blood group or HLA antigens can damage endothelial cells in the renal allograft by activation of the complement cascade. Eculizumab inhibits complement protein $\mathrm{C} 5$ preventing formation of the membrane attack complex and protects the graft from the deleterious effect of circulating antibody. Eculizumab is being increasingly used in the treatment of antibody-mediated rejection (AMR) in combination with antibody removal. A supplementary dose of eculizumab is recommended after each plasma exchange procedure to ensure a therapeutic concentration. There are no studies evaluating the need for eculizumab replacement after double filtration plasmapheresis (DFPP) and immunoadsorption (IA).

\section{Methods}

We have measured levels of eculizumab before and after DFPP and Therasorb IA in a patient treated for antibody-mediated rejection. Drug levels over time were calculated using the formula $\mathrm{C} 1=\mathrm{C} 0^{\star} \mathrm{e}^{\wedge}\left(-\log / \mathrm{T}^{\star} \mathrm{t}\right)$, where $\mathrm{C} 1=$ concentration after time $\mathrm{t}, \mathrm{CO}=$ initial concentration, $\mathrm{T}=$ half-life.

\section{Results}

Eculizumab concentration decreased from $265.3 \mathrm{ug} / \mathrm{mL}$ to 114.8 $\mathrm{ug} / \mathrm{mL}$ after DFPP and from $168.7 \mathrm{ug} / \mathrm{mL}$ to $109.9 \mathrm{ug} / \mathrm{mL}$ after Therasorb IA (43.7\% and $65.1 \%$ of the concentration prior to antibody removal procedure, respectively).

Taking into consideration the half-life of eculizumab (on average $261-271$ hours), in both cases a concentration higher than 50 $\mu \mathrm{g} / \mathrm{mL}$ (recommended concentration in the treatment of aHUS) would persist for 12 days (313 - 325 and 297 - 308 hours respectively).
A supplementary dose of $600 \mathrm{mg}$ was given in both cases with peak levels after 1 hour of infusion of $347.9 \mathrm{ug} / \mathrm{mL}$ and $257.2 \mathrm{ug} /$ $\mathrm{mL}$ respectively. A concentration higher than $50 \mu \mathrm{g} / \mathrm{mL}$ would last for at least 26 days $(730$ - 758 and 617 - 649 hours respectively).

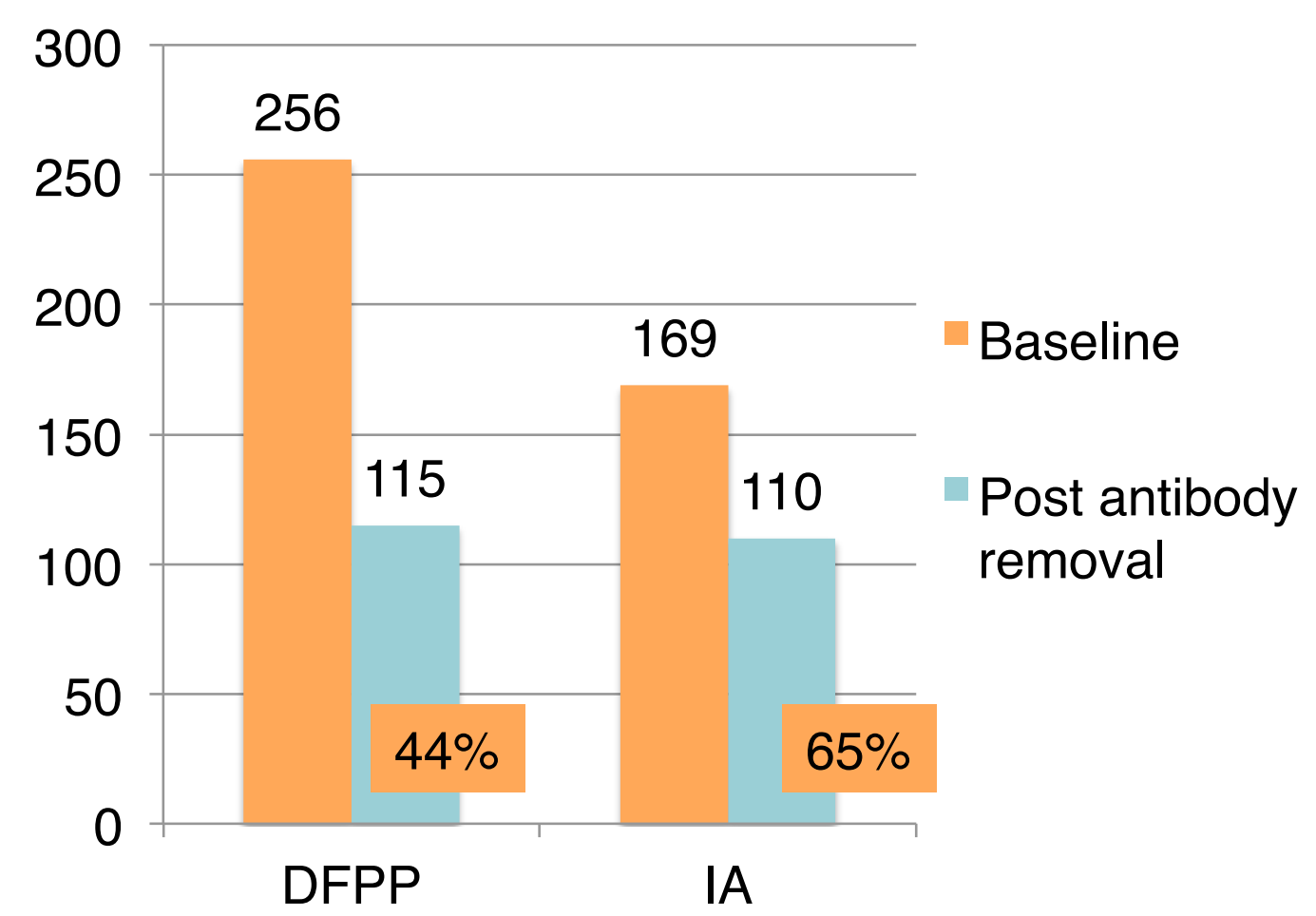

Figure 1. Comparison of percent decrease in eculizumab concentrations after different types of antibody removal sessions. Between DFPP and IA the difference is $21 \%$. Eculizumab concentration is given in $\mathrm{ug} / \mathrm{mL}$.

\section{Discussion}

Even though Eculizumab concentration decreases during DFPP and Therasorb IA, a supplementary dose is probably not necessary after a single antibody removal procedure. It should be consider if two or more antibody removal sessions are required.

\section{References}

Eculizumab Parker CJ, Kar S, Kirkpatrick P. Nat Rev Drug Discov. 2007 Jul;6(7):515-6.

The use of eculizumab in renal transplantation. Barnett AN et al. Clin Transplant. 2013 May-Jun;27(3):E216-29.

\section{Guy's and St Thomas' WHS} NHS Foundation Trust

\begin{tabular}{l} 
KING'S \\
LONDOllege \\
\hline
\end{tabular}

www.kcl.ac.uk

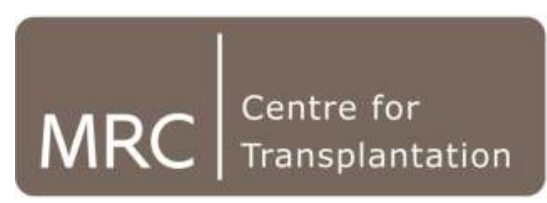

$\begin{array}{ll}1 & 1 \\ 1 & 1\end{array}$
II II I | inlint KING'S Iloul ifil ini in HEALTH i I is in il ailli loil PARTNERS 